Sugerowane cytowanie:

Zdun, M. (2020). Przedsiębiorczość w dobie pandemii SARS-CoV-2. Próba identyfikacji konceptualnych pól analizy i modeli urzeczywistnienia gospodarczej inicjatywy. W: M. Ćwiklicki, K. Sienkiewicz-Małyjurek, (red.). Ekonomia Społeczna. Przedsiębiorczość społeczna w czasie kryzysu (s. 37-53). Kraków: Uniwersytet Ekonomiczny w Krakowie. https://doi.org/10.15678/ES.2020.2.04

\title{
Przedsiębiorczość w dobie pandemii SARS-CoV-2. Próba identyfikacji konceptualnych pól analizy i modeli urzeczywistnienia gospodarczej inicjatywy
}

\author{
Magdalena Zdun
}

Streszczenie: Głównym zamierzeniem artykułu jest stworzenie narzędzia analizy i typologii przedsiębiorczości. Jej poszczególne typy stanowić będą możliwe do urzeczywistnienia się modele gospodarczej inicjatywy w dobie pandemii wirusa SARS-CoV-2. Ambicją artykułu staje się w ten sposób prezentacja „wzorców idealno-typowych”, służących diagnozie przedsiębiorczości ex ante i ex post pandemicznych wydarzeń.

Artykuł ma charakter teoretyczny, a jego metodą jest dyskusja stanowisk, pojęć i koncepcji. Analiza prowadzi do wskazania czterech podstawowych modeli przedsiębiorczości, których szanse i zagrożenia wydobywa na światło dzienne epidemiczna sceneria. Konceptualna diagnoza typów idealnych przedsiębiorczości finalnie prowadzi do wskazania „Wzorca przyszłość”. Jest nim „przedsiębiorczość relacyjna", która łączy w sobie obszar uspołecznia i indywidualnych aspiracji. Zestawia też ze sobą dwie podstawowe formy użyteczności: ekonomiczną i moralną.

Słowa kluczowe: przedsiębiorczość; pandemia; aksjologia; modele człowieka gospodarującego.

Kody JEL: $\quad$ A14, Z13

\section{Wstęp}

O przedsiębiorczości napisano już bardzo wiele. Kategoria ta była zarówno częstym tematem analizy naukowej i eksperckiej, jak również ciekawym wątkiem filmowym i literackim. Jej sfabularyzowanie nierzadko służyło diagnozie zastanego porządku rzeczy, a emploi przedsiębiorcy pozwalało na oszacowanie siły i kondycji człowieczeństwa per se. Tak było w przypadku wielu ważnych dzieł: Lalki, Ziemi Obiecanej, czy Buddenbroków. Przykłady te powalają stwierdzić, że przedsiębiorczość jest kategorią szczególnie ciekawą, a jej rozpoznanie przyczynia się do analizy kwestii bardziej ogólnych, w tym wielkich kryzysów, wystawiających na próbę człowieczą naturę. Nie inaczej jest dzisiaj, kiedy to pandemia wirusa SARS CoV-2 powołuje do istnienia nowe odmiany gospodarczej inicjatywy i dopinguje do refleksji nad naturą człowieka.

Skrojona na miarę trudnej sytuacji przedsiębiorczość daje się rozpoznać jako narzędzie regulacji i okiełznania społeczno-gospodarczego impasu. Na skutek tego określić ją można jako kategorię trans-graniczną. Występuje ona zarówno w roli explanansu i explanandum 
zmiany społecznej. Z jednej bowiem strony jest ona przedmiotem wyjaśnienia; z drugiej - to ona wyjaśnia świat i odpowiada za jego dynamikę. Przedsiębiorczość czasu kryzysu opisać można również jako kategorię unieważniającą konflikt pomiędzy redukcjonizmem i realizmem metodologicznym. Jej analiza wymaga porzucenia założeń ściśle atomistycznych, w myśl których inicjatywa gospodarcza jest wynikiem intencjonalnych działań jednostki i niczym więcej, jak również dopinguje do tego, by nie poddać się dyktaturze systemowej i uczynić zeń zakładnika systemu społecznego. W rezultacie przedsiębiorczość daje się poznać jako kategoria ontologicznie niedomknięta: jest ona fenomenem społecznym, który się nieustannie zmienia. Ontologia ta realizuje się w dwóch odmianach: rzeczywistej i ideacyjnej. Pierwsza dotyczy tego, co możliwe do zaobserwowania; druga - jest "typem idealnym”, modelem stworzonym (tylko i aż) po to, by mierzyć odstępstwo o zdefiniowanej formuły.

W kontekście tych ustaleń najistotniejsze wydaje się stworzenie konceptualnego schematu, wydobywającego na światło dzienne trans-graniczność przedsiębiorczości. Pozwoli on określić podstawowe modele gospodarczej inicjatywy i zidentyfikować pola jej analizy. Taki też jest cel niniejszego artykułu.

Głównym zamierzeniem pracy jest stworzenie typologii przedsiębiorczości. Jej poszczególne typy stanowić będą możliwe do urzeczywistnienia się modele gospodarczej inicjatywy w dobie pandemii wirusa SARS-CoV-2. Tym samym ambicją artykułu staje się prezentacja „Wzorców ideolo-typowych", które traktować ostatecznie należy jako narzędzie porównania i diagnozy dostępnych w rzeczywistości form realizacji.

Punktem wyjścia tej analizy będzie stworzenie właściwej konstrukcji pojęciowej, dla której zasadnicze wydaje się ustalenie, że przedsiębiorczość kształtuje się zarówno w oparciu o oczekiwania systemowe, jak i osobiste aspiracje. Dlatego też realizuje się ona w sferze prywatnej i przestrzeni publicznej. Łączy w sobie przy tym obszar wartościowania i praktykowania; zestawia etosowość z racjonalizmem. W rezultacie, jej konstrukcja wspiera się na intuicyjnym i ugruntowanym w literaturze socjologicznej podziale na działania racjonalne i emocjonalne (logiczne i nielogiczne), które z kolei znajdują dwa podstawowe obszary urzeczywistnia: prywatny i publiczny.

\section{Działania racjonalne i emocjonalne, czyli pierwsza oś schematu}

Pojęcie działania społecznego rozsławił M. Weber (2005). Pojęcie to jednak nie jest jego konceptualnym dziełem. Do pionierów analizy działania zaliczyć trzeba włoskiego intelektualistę V. Pareto (1975). To właśnie ten myśliciel wprowadza najbardziej ogólny podział działań, grupując je na logiczne i nielogiczne. Rozróżnienie to grosso modo odpowiada zaordynowanemu później przez Webera podziałowi działań na afektywne i racjonalne (Weber, 2005, s. 46-59). Stworzoną przez siebie dychotomię, V. Pareto zapisuje w „Teorii nielogicznego działania". Na łamach tego dzieła stwierdza nie tylko istnienie dwóch podstawowych typów działania, ale również zauważa, że tylko jedno z nich, charakteryzuje się właściwym dopasowaniem środków do celów. To dopasowanie jest typowe dla działań logicznych. Jest też możliwe do stwierdzenia przez obserwatorów zewnętrznych. V. Pareto przekonuje, że większość działań ma charakter nielogiczny, a więc nie da się w ich przypadku zaobserwować przyczynowo-skutkowej zależności pomiędzy środkiem i celem (Pareto, 1964, par. 2143). Nielogiczne działania posiadają dodatkowo ciekawą właściwość. Istnieją dla nich ideologiczne uzasadnienia. Wyjaśnieniu zależności pomiędzy nielogicznym działaniem a jego uzasadnieniem służy właściwa sprawie aparatura pojęciowa - terminologiczne rozróżnienie na rezydua i derywacje. Pierwsze 
ze wskazanych obejmuje obszar irracjonalności, instynktu. Derywacje to zaś pseudologiczne uzasadnienia, propaganda uzasadniająca nielogiczne działanie i nie podlegają one ocenie wedle kryteriów prawdziwości (Sztompka, 2020, p. 257).

Kryterium rozróżnienia działań zaproponowane przez Pareto jest zdecydowanie nieostre (Bauman, 1959, s. 13). Ucieka się bowiem do opinii innych, czy też: bazuje na tym, „co inni sądzą na temat". Niemniej dostarcza ono istotnego konceptualnie rozróżnienia. Pozwala ono wykreślić pierwszą linię schematu. Linia ta to continuum pomiędzy tym, co logiczne i nielogiczne; racjonalne i emocjonalne. Łączy ona przeciwstawne sposoby realizacji i uprzyczynowienia przedsiębiorczości, eksponując w ten sposób jej transgraniczną naturę. Takim też tropem, jako pionier tematyki, zmierzał M. Weber (1994). W dziele „Etyka protestancka i duch kapitalizmu” dowodził, że przedsiębiorczość łączy w sobie racjonalność i wartościowanie oraz spaja dwa przeciwstawne porządki: transcendentalny i świecki.

\section{Prywatne i publiczne, czyli druga oś schematu}

Druga oś konstrukcyjna zestawia ze sobą obszary urzeczywistniania gospodarczej inicjatywy: sferę prywatną i publiczną. Podział na publiczne i prywatne, jak przekonują M. Marody i A. Giza-Poleszczuk (2004, s. 260), legitymuje się łacińską etymologią. Znaczeniowe sedno tychże terminów uformowało się jeszcze w czasach Starożytnych przed przejściem od prawa rzymskiego w stronę praw zwyczajowych. Wpracowane wówczas rozróżnienie zostało podtrzymane w Wiekach Średnich i zapisało się w leksykonach XIX-wiecznej Europy. Już wówczas rozumienie tych terminów, opierało się na zasadzie znaczeniowego przeciwstawienia. Z pism pozostawionych przez Cycerona dowiadujemy się, że terminem privus oznaczano to co partykularne i osobiste. Pojęciem privatum - wykazującym wybitne pokrewieństwo z źródłosłowem - opisywano zaś majątek własny jednostki, a określeniem privatim charakteryzowano "działanie na swoim".

Wręcz przeciwstawny jest sens pojęcia „publiczny”. Termin ten ukierunkowuje w stronę obszaru uwspólnotowienia. M. Marody i A. Giza-Poleszczuk tłumaczą sens tej kategorii, odwołując się do zapisów z ksiąg średniowiecznych. Badaczki te przekonują, że w myśl ówczesnych ustaleń, podstawową cechą obszaru publicznego była zależność od władzy suwerennej. Dlatego też pojęcie persona publica oznaczało osobę, która działa w imieniu ludu, broni praw wspólnoty, a nie w imię korzyści własnych i bezpieczeństwa swojego domu. W ten też sposób, to co publiczne zaczyna przeciwstawiać się wszystkiemu, co oswojone i familiarne oraz osobiste, intymne, spersonalizowane. Sfera publiczna zaczyna też posługiwać się sobie właściwym prawem i zasadami życia zbiorowego. „Tworzy «ona ramy» ujawniania się jednostek, wyprowadzania ich z zamkniętych światów życia prywatnego" (Marody, Giza-Poleszczuk, 2004, s. 265). Jest przez to waloryzowana pod kątem posiadania cech takich jak: przejrzystość reguł, równość jej uczestników i współtwórców, czy racjonalność odbywających się w niej dyskursów (Marody, Giza-Poleszczuk, 2004, s. 265).

\section{Konceptualny schemat analizy przedsiębiorczości i pola jej urzeczywistnienia}

Oba wskazane tu obszary (prywatności i upublicznienia) określić można mianem pól urzeczywistnienia się przedsiębiorczości. Ta bowiem realizować może się zarówno jako czyn jednostki, jak również podlega procesowi wspólnotowej regulacji, a nawet systemowej depersonalizacji. Z kolei dwa wskazane typy działań to pobudki przedsiębiorczości. 
Schemat konceptualny analizy przedsiębiorczości (rysunek 1) wyznaczony zostaje przed dwie skrzyżowane ze sobą osie. Pierwsza z nich - pionowa - łączy ze sobą racjonalności i sferę afektu. Swym wektorem eksponuje jednocześnie typowy dla współczesności kierunek przejścia: od racjonalnych potrzeb do zmysłowych pragnień. Oś druga - niejako wykreślająca "drugą symetrię układu" - zestawia przeciwstawne obszary realizacji przedsiębiorczości: prywatny i publiczny. Wektor tej osi wyraża również właściwą dla ponowoczesności transpozycję (Marody, 2015, s. 80). Polega ona na eksportowaniu jednostkowych przeżyć oraz interesów do obszaru publicznego. Zjawisko to, zdaniem M. Marody, jest symptomatyczne dla współczesności. To efekt zwolnienia jednostki z obowiązków obywatelskich przez system demokracji przedstawicielskiej. To także sposób na to, by jednostka spotęgowała zainteresowanie samą sobą i budowała mury bezpiecznego królestwa prywatności.

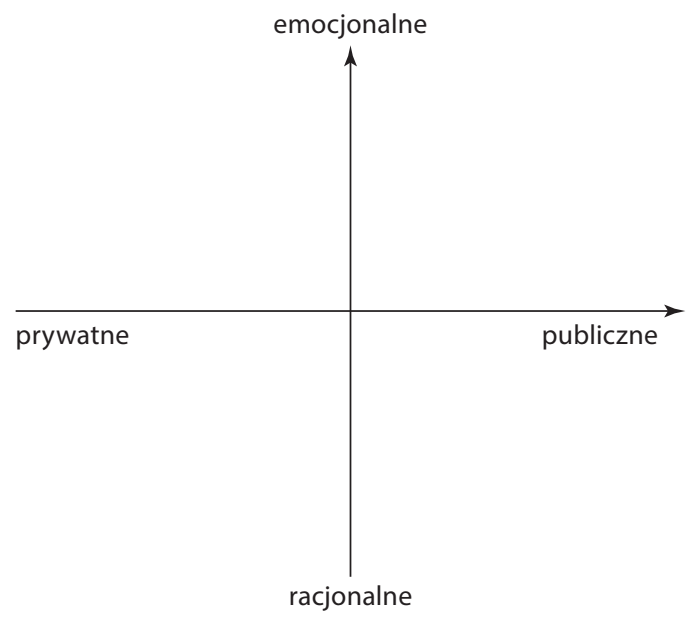

Rysunek 1. Konceptualny schemat analizy przedsiębiorczości

Źródło: opracowanie własne.

\section{Konceptualne pola analizy}

Łącznie, dwie skrzyżowane ze sobą osie wyznaczą cztery pola konceptualne, które z kolei pozwalają wskazać zasadnicze typy współczesnej przedsiębiorczości (rysunek 2).

Pole pierwsze powstaje poprzez skrzyżowanie obszaru prywatności ze sferą racjonalną. Biorąc pod uwagę wektory osi konstrukcyjnych, ćwiartkę tę uznać należy na wyjściową. Łączy się w niej myślenie obrachunkowe z przywiązaniem do „świata własnego”, odizolowanego, prywatnego. Racjonalność wymusza kalkulację zysków i strat. Kształtuje też specyficzny, skrajnie zmaterializowany, ogląd rzeczywistości i buduje sobie właściwy światopogląd obrachunkowy, przypisany przez W. Sombarta (2010) do kapitalizmu. Wysuwa on na plan pierwszy kategorię opłacalności i przewidywalności. Z kolei pojęcie prywatności żąda koncentracji na sobie samym i w ten też sposób wszelkie kalkulacje przypisuje do działającego intencjonalnie podmiotu. W rezultacie zapleczem teoretycznym ćwiartki pierwszej staje się socjologiczna koncepcja racjonalności i teoria racjonalnego wyboru (Colemen, 2008). 


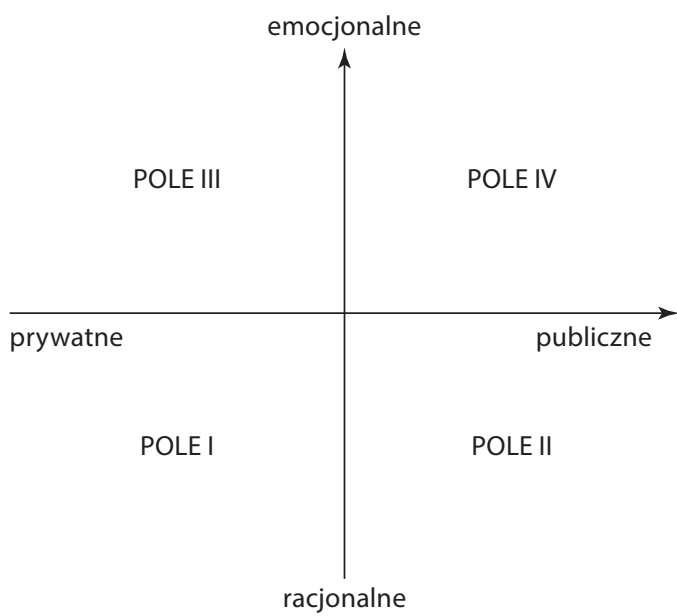

\section{Rysunek 2. Konceptualne pola analizy przedsiębiorczości}

Źródło: opracowanie własne.

Pole drugie powstaje poprzez skrzyżowanie obszaru racjonalności ze sferą publiczną. Dochodzi w nim do przeniesienia refleksyjności obrachunkowej z jednostki na sferę upublicznienia, tj. poziom społeczeństwa. Dlatego też zapleczem teoretycznym ćwiartki drugiej jest socjologiczna koncepcja systemu. Pozwala ona wyjaśnić zjawisko transpozycji racjonalności, przy założeniu, że obszar upublicznienie potraktujemy jako ponadjednostkową całość - system społeczny. Sięgająca korzeniami XIX-wiecznego organicyzmu koncepcja systemu ujmuje społeczeństwo jako całość, funkcjonującą wedle określonej zasady. W myśl tych założeń, system dysponuje sobie właściwą strukturą i jest zróżnicowany funkcjonalnie. Neoewolucjonista T. Parsons będzie przekonywał, że jest on kategorią analityczną par excellence, a o jego specyfice przesądza ład (Parsons, 2009). Dzięki ładowi system „zna sam siebie” i działa według jasnych reguł. Przypisuje też jednostce miejsce w systemie i wymaga wykonania na jego rzecz określonej pracy (Parsons, Shils, Olds, 2006, s. 376).

Pole trzecie powstaje poprzez skrzyżowanie obszaru prywatności ze sferą emocjonalną. W obszarze tym kumulują się czynniki przypisane do jednostki: prywatność i emocjonalność. Z tej też przyczyny zapleczem teoretycznym tego obszaru są niektóre ustalenia psychologii egzystencjalnej oraz koncepcja działań nielogicznych V. Pareto. Czerpiąca z pism S. Kierkegaarda i M. Heideggera psychologia egzystencjalna przyjmuje, że człowiek to jednostka zagubiona i poszukującą, którą badać trzeba poprzez opis jej doświadczenia (Oleś, 2005, s. 315). Zmaga się ona z poczuciem braku pewności i możliwości podejmowania trafnych decyzji. Jednocześnie wyznacza sobie cele i kierunki działania, ale nigdy nie jest pewna, czy podąża w właściwą stronę. Dysponuje przez to sobie właściwą formą racjonalności - jest to racjonalność egzystencjalna. Zgodnie z nią opłaca się podejmować te działania, które prowadzą od odkrycia lub podtrzymania sensu życia.

Pole czwarte powstaje poprzez skrzyżowanie obszarów emocjonalności i upublicznienia. Z tej też przyczyny do ćwiartki tej prowadzi aparatura pojęciowa stworzona właśnie przez Pareto. Derywacje nie tylko racjonalizują irracjonalność, ale również wyprowadzają emocje z poziomu jednostkowego i upubliczniają je za pomocą ideologicznego kamuflażu. Zbiór uzasadnień, wskazany przez Pareto, ma charakter międzypodmiotowy. To obszar inter- 
subiektywny - ufundowany na społecznej podzielności znaczeń i symboli. Dochodzi w nim, a przynajmniej dojść powinno, do ważnej transpozycji: przejścia z obszaru emocjonalności w obszar wartościowania. Za proces ten odpowiadają znaki, a ściślej rzecz ujmując - symbole, czyli szczególna ich odmiana. „Człowiek - zauważa A. Kłoskowska - jest zdolny do ujmowania samego siebie i otaczającego go świata w sposób refleksyjny, tzn. semiotyczny, dokonujący się za pomocą znaków społecznie ustalonych - właściwych ludzkiej «naturze gatunkowej»" (Kłoskowska, 2007, s. 98). W sferze symboli i znaków - przekonuje dalej Kłoskowska (2007, s. 105) - „ludzie formułują oceny i normy oraz szukają przeżyć, które nie wiążą się ze świadomym dążeniem do osiągniecia jakiegoś praktycznego celu, lecz są kierowane pragnieniem samego doświadczenia wartości". Dlatego też obszar ten ogrywa rolę szczególną: dochodzi w nim do upublicznienia emocjonalności i przeniesienia afektu w obszar wartościowania. Ot, kryterium aksjologiczne tej części schematu.

\section{Modele człowieka gospodarującego}

Do każdej ze wskazanych ćwiartek daje się przypisać odpowiedni model człowieka gospodarującego i powiązany z nim typ przedsiębiorczości.

Pole pierwsze jest terenem homo ocenonomicus, człowieka ekonomicznego, którego definiuje kalkulacja kosztów i korzyści. Autorstwo tego modelu, w sposób błędny przypisywane jest A. Smithowi. Badacz ten, co prawda wysuwa na plan pierwszy egoistyczny charakter usposobienia człowieka gospodarującego, ale również nie odmawia mu wrażliwości i cech altruistycznych. W myśl przyjętych przez Smitha założeń, człowiek z jednej strony dąży do maksymalizacji swoich korzyści, z drugiej - wkomponowuje uczucia w relacje gospodarcze, kierując się w swych działaniach sympatią do innych. „Człowiek - zauważy Smith - może istnieć jedynie w społeczeństwie” (Smith, 1989, s. 146), a za przynależność tę zawdzięcza „uczuciom moralnym" (Giza-Poleszczuk, 2010, s. 252).

Takim sprzecznościom opiera się całkowicie koncepcja stworzona przez J.S. Milla. Przedstawia ona nieskażony emocjonalnością model homo oeconomicus. Mill dzieli się nim w eseju On the Definition of Political Economy (Dzionek-Kozłowska, 2018, s. 23). Praca ta miała na celu przede wszystkim ugruntowanie statusu ekonomii politycznej. W rzeczywistości dostarczyła jednego $z$ bardziej rozpoznawalnego $w$ fachowej literaturze i dyskusjach publicznych modelu człowieczeństwa. Mill przypisuje człowiekowi ekonomicznemu dążenie dóbr i pomnażania bogactwa. Czyni zeń rachmistrza zysków i strat. Ekonomia bowiem - w myśl przyjętych przez Milla założeń - winna traktować istotę ludzką, jako zajętą „zdobywaniem i konsumowaniem bogactwa" (Mill, 1836/1967, s. 322). Taki też model człowieka pozwala zlekceważyć inne „namiętności”, do których Mill zalicza wstręt do pracy i folgowanie sobie w uciechach (Dzionek-Kozłowska, 2018, s. 32).

W myśl założeń przyjętych przez Milla bogacenie staje się psychologicznym prawem aktywności człowieka. Na tym jednak wydaje się kończyć millowska szkoła psychologizacji. Poza chęcią pomnażania dóbr człowiek zostaje tutaj odarty z wszelkich innych emocjonalnych przymiotów. Nie znaczy to - pisze Mill, komentując sprawę - iżby jakiś ekonomista myślał kiedykolwiek tak niedorzecznie, by przyjmować, że ludzie rzeczywiście mają taką konstytucję psychiczną" (Mill 1962, s. 634). Impulsy innej natury istnieją, ale to racjonalny wybór ukierunkowany na pomnażanie dóbr jest kwintesencją aktywności ekonomicznej (Dzionek-Kozłowska 2018, s. 34).

Brytyjska teoretyk społeczeństwa M. Archer (2013) łączy z kolei model homo oeconomicus z wzorem człowieka nowoczesności i atomistyczną perspektywą badania społeczeństwa. 
Racjonalność, jej zdaniem, jest osią konstrukcyjną człowieka ekonomicznego. Pojawienie się tej postaci wydaje się jednak Archer nieodgadnioną zagadką. „Człowiek nowoczesności - pisze brytyjska socjolog - przypominał w dużym stopniu osiemnastowiecznego Clinta Eastwooda, samotnego nieznajomego, który kroczył z podniesionym czołem przez przedmieścia zachodniego świata; człowieka znikąd, który przybył do skonstruowanej już rzeczywistości (...)" (Archer, 2013, s. 54). Od tej zagadkowej postaci nauczono wymagać się jednego: by w swych działaniach był racjonalny i uzasadniał podejmowane przez siebie decyzje. "W tym też sensie - dalej argumentuje Archer (2013, s. 55) - człowiek nowoczesności stał się logocentryczny. Jeśli zawdzięcza on cokolwiek wspólnocie (zamiast zawdzięczać jej wszystko), tym czymś jest racjonalne uzasadnienie jego działań". Ten typ człowieka daje się też opisać jako łowca ofert i okazji, bywalec i uczestnik światowego rynku, na którym negocjuje korzystne warunki dla siebie i dokonuje opłacalnych transakcji. Człowiek nowoczesny bez końca uczestniczy w transakcji wymiany i do procesu tego dopuszcza nawet relacje, które takowemu handlowi podlegać nie powinny. Tak też okazuje się, że może on być lojalny wyłącznie wobec własnych pragnień (Archer, 2013, s. 57). Jest radykalnie odizolowany, a działania jego podporządkowane są jego indywidualnym dyspozycjom.

Do modelu tego pasuje „przedsiębiorczość zadaniowa”, której kwintesencją jest materialny zysk. Ten typ przedsiębiorczości opiera się na zinstrumentalizowaniu roli przedsiębiorcy. Przedsiębiorca, w myśl tych założeń, to czciciel wielkości rozumu, istota wyizolowana i samotna, poruszająca się po świecie w oparciu o kompas, którego wskazówki ciągną do bieguna racjonalności. Wzorzec ten na plan dalszy spycha kwestię uczestnictwa w innych porządkach, lekceważy znaczenie kapitału moralnego. Instrumentalna racjonalność oczyszcza bowiem rynkowego gracza z emocjonalności i sprawia, że relacje z innymi przestają odgrywać rolę w kształtowaniu jego tożsamości. Nie jest on zdolny do przekroczenia granic wyznaczonych przez konstrukcje rozumu instrumentalnego, dlatego też nie zajmuje się on "troskami ostatecznymi” i nie dąży do tego, by określić kim tak naprawdę jest (Archer, 2013, s. 8).

Model człowieka ekonomicznego pozwala ująć przedsiębiorczość w sposób skrajnie zinstrumentalizowany. Wspiera się ona na kalkulacji koszów i korzyści. Właściwa jej jest również umiejętność trafnego podejmowania decyzji. Podstawowym uzasadnieniem przedsiębiorczości, która formuje się w polu sprywatyzowania racjonalności jest indywidualny zysk. Takie myślenie izoluje społecznie przedsiębiorcę i ogołaca rolę biznesmena z relacji społecznych. Zwalnia go też całkowicie ze społecznej odpowiedzialności. Pozwala przyjąć, że rola społeczna przedsiębiorcy wcale nie jest "strategią infekcyjną" wikłającą w kontakty z innymi - jak chciałby tego interakcjonista G. Mead. To raczej struktura samorealizacji, do której przypisane są konkretne zadania do wykonania. To pozycja o charakterze instrumentalnym wymagająca posiadania konkretnych zasobów i kwalifikacji. Jej naturalną motywacją jest zysk, a metodą działania - kalkulacja oraz decyzyjność. Przedsiębiorca realizuje zadania, na które całość społeczna zgłasza zapotrzebowania i w tym tylko sensie "uspołecznia się”. Jest to rzecz jasna: pozorne i „samolubne uspołecznienie”. Jej rysem charakterystycznym jest reedukacja materialistyczna. Znajduje ona wyraz w obrachunku opłacalności, nierzadko skutkującym dewastacją porządku naturalnego (poprzez eksploatowanie środowiska) i społecznego (na skutek atomizacji i instrumentalizacji międzypodmiotowych powiązań).

Kwintesencją drugiego pola jest „depersonalizacja racjonalności”. Racjonalność na skutek przeniesienia się w obszar systemu społecznego przestaje być przymiotem jednostki. Staje się zaś cechą całości społecznej. W rezultacie formuje przedsiębiorczość, podlegającą procesowi depersonalizacji i anonimizacji. Realizuje się ona w strukturze homo sociologicus - istoty 
społecznej. Jest ona wyraźnie skontrastowana pod względem cech i „struktury" z człowiekiem nowoczesności i wzorcem homo oecnonmicus. Istota społeczna, jak przekonuje Archer, nabywa od społeczeństwa wszystko prócz biologicznej konstrukcji. Efektem socjalizacji jest również wyróżniająca dla gatunku ludzkiego umiejętność - zdolność manipulowania znaczeniami. Istota społeczna jest „ontologicznie wtórna wobec istoty ludzkiej” (Archer, 2013, s. XLVII). Przez to też "skonstruowany" na tej bazie przedsiębiorca staje się całkowitym niewolnikiem systemu. Jego rola społeczna nie podlega jakiejkolwiek personalizacji, a służy jedynie realizacji konkretnych zadań wyznaczonych przez system społeczny. W bardziej radykalnej wersji "depersonalizacji racjonalności" jednostka zostaje zlikwidowana całkowicie. Staje się ona niemym narzędziem systemu. System działa zaś zgodnie ze swoją logiką i realizuje za pomocą swego wewnętrznego ładu projekt „przedsiębiorczości zdepersonalizowanej”. Model ten opisuje J. Schumpeter, choć nie wyjawia ustalenia na temat "likwidacji indywiduum" expressis verbis. Austriacki socjo-ekonomista kojarzy depersonalizację przedsiębiorczości z ustrojem socjalistycznym i jego utopią. W układzie tym przedsiębiorczość realizuje się poprzez racjonalność systemową (Schumpeter, 1995).

Socjalizm w swej idealno-typowej formule, jak przekonuje Schumpeter, miałby się stać dziejowym następcą kapitalizmu. W jego strukturach przedsiębiorca zamieni się w administratora koordynującego działania. „Przedsiębiorcy i kapitaliści - pisze Schumpeter (1995, s. 193) - w istocie rzeczy cała warstwa, która akceptuje burżuazyjny model życia przestanie istnieć". Gospodarka stanie się bezosobowa i zautomatyzowana, a praca w biurze będzie wypierać indywidualny czyn. Przedsiębiorca w rezultacie przekształci się w najemnego dyrektora, kierownika lub też urzędnika niższego szczebla. Jego nowa formuła obali też mit przedsiębiorcy kapitalistycznego, który opisywany jest przez Schumpetera jako dysponent szczególnych talentów, korzystający z radości tworzenia i urzeczywistniający swoje marzenia o budowie „prywatnych królestw”, lepszego świata.

Według Schumpetera socjalistyczna utopia to kolejny szczebel w rozwoju i sposób na urzeczywistnienie się "systemowego racjonalizmu”. Jest w nim miejsce zarówno na demokrację jak i racjonalność. To zbiurokratyzowana maszyna, działająca bez szwanku, zgodnie ze swoją zasadą i typem racjonalności. M. Weber wskazuje jej dwa podstawowe rodzaje: formalną i materialną. W przypadku pierwszym system opiera swe strategie na czystej kalkulacji opłacalności; w drugim zaś - dokonuje obrachunków w kontekście aksjologicznym, biorąc pod uwagę wartości kluczowe do zrealizowania. Wówczas też odwołuje się do swojego ładu i struktury sensu, która w myśl założeń przyjętych przez T. Parsonsa (2009), a później N. Luhmanna (2007), jego kwintesencją. W systemie takim „przedsiębiorcom - pisze Schumpeter (1995, s. 161) - nic już nie pozostanie do zrobienia. Znajdą się w sytuacji bardzo przypominającej położenie generałów w społeczeństwie, które na trwałe zapewniło sobie pokój". W konsekwencji obowiązek obrachunkowości i pomnażania indywidualnych zysków zostaje z nich zdjęty i przeniesiony na system. Przedmiotem kalkulacji staje się w rezultacie ekonomiczne bezpieczeństwo całości.

Schumpeter swoją utopijną wizję przedsiębiorczości w socjalizmie ustawia w chronologii dziejowej krok za kapitalizmem. To etap, w którym dochodzi do zastąpienia troski siebie polityką materialnego bezpieczeństwa (Schumpeter, 1995, s. 212). Ten typ ustroju cechuje się „kulturową nieokreślonością", a jej wyznacznikiem jest bezosobowość gospodarcza i racjonalność, która się realizuje „poprzez akt polityczny, (...) poprzez ustanowienie wspólnoty” (Schumpeter, 1995, s. 216).

Pole trzecie z kolei podtrzymuje wizję przedsiębiorcy-charyzmatyka, z którą bezlitośnie miała się rozprawić schumpeterowska utopia socjalizmu. Obszar trzeci - zgodnie ze wskaza- 
niami osi układu - wywodzi się z pola pierwszego. Różnica w genezie jednak jest zasadnicza: tkwi w wymiarze poddawanym transpozycji. Podczas gdy ćwiartka druga (poprzez zabieg zmiany perspektywy odniesienia) odchodzi od modelu człowieka ekonomicznego i ukierunkowuje się w stronę istoty społecznej; tak ćwiartka trzecia staje się odpowiedzialna za przejście do homo oeconomicus w stronę homo sensitivo (człowieka wrażliwego).

Pole trzecie formuje się w oparciu emocjonalność i prywatność. Z tego też powodu wydaje się neutralnym terytorium popędu i instynktu - czy jak chce tego Pareto - derywacji. Przyjąć tu należy, że działania człowieka w zasadzie mają charakter irracjonalny i poszukują jedynie logicznych uzasadnień. Obszar ten odsłania w ten sposób afektywną naturę człowieka i pozwala przyjąć, że podejmowane przezeń działania mają nieracjonalne pobudki. Jednocześnie pole trzecie znajduje się w granicach przynależnych do prywatności. To zaś oznacza, że na jednostkę traktować trzeba jako „emocjonalny podmiot działania”, który buduje własną biografię i konstruuje jej „strukturę sensu egzystencji”. Takie myślenie o człowieku w gospodarce, paradoksalnie zapoczątkował ojciec ekonomii - A. Smith, przyznając, że jednostka w swych działaniach kieruje się nie tylko kalkulacją, ale również sympatią wobec innych. Wydaje się jednak, że Smith osadza emocjonalność na pozycji zależnej względem racjonalności, jest czymś wobec niej wtórnym. Pisze bowiem tak: „Jeśli nam nie dolega żadna troska, rozum nie powiadomi nas w żadnym przypadku, jak cierpi nasz bliźni, choćby nawet przechodził męki. Nigdy też nie pozwoli wyjść poza nasze własne przeżycia i nie jest w stanie tego uczynić, zaś pojęcie doznań innego człowieka jest możliwe jedynie za sprawą wyobraźni". Współodczuwanie jest zatem "pracą do wykonania” (Dzionek-Kozłowska, 2018, s. 42), kwalifikacją, którą człowieka musi w sobie wypracować, po to by dobrze rozpoznawać potrzeby innych. „Człowiek - pisze Smith - natomiast prawie ciągle potrzebuje pomocy swoich bliźnich i na próżno szukałby jej jedynie w ich życzliwości. Jest bardziej prawdopodobne, że nakłoni ich do pomocy, gdy potrafi przemówić do ich egoizmu i pokazać im, że jest dla nich samych korzystne, by zrobili to, czego od nich żąda" (Smith, 2007, vol. I, s. 20-21). Tak też okazuje się, tkwiący w sednie natury ludzkiej afekt, daje asumpt nie tylko do zepsucia i rozwoju wad, ale również stanowi zarzewie społecznych cnót. To zaś pozwala stwierdzić, że emocjonalność zwraca jednostkę w stronę świata wartości niematerialnych, takich jak uczciwość, czy sprawiedliwość (Etzioni, 1988) będzie zaś przekonywała, że orientacja na wartości wręcz pozbawia możliwości dokonywania wyboru i aktywuje prawo „użyteczności moralnej”.

Trudny do uchwycenia „impuls moralny" przesądza o gatunkowej specyfice i „wyjątkowości człowieka". Pozwala też rozszerzyć obszar motywacyjny przedsiębiorcy o obszar wartości i degradować znaczenie samego zysku. Taki model człowieka w gospodarce przekierowuje uwagę w stronę wartości niematerialnych, w tym sferę transcendentalną. Tropem tym zmierza M. Weber (1994), który za podstawowe uzasadnienie przedsiębiorczości uzna poddanie się protestanckiej idei predestynacji. Tak też Weber dokona sztuki powiązania "zamożności" i „pobożności”, wartości materialnych z wartościami egzystencjalnymi, czy też: bogacenia się ze strukturą egzystencjalnego sensu. Przetransponuje też model homo oeconomicus w stronę wzorca homo religiosus, dowodząc, że koncentracja na wartościach egzystencjalnych, wsparta „inwestycjami” w obszar cnót, służyć może gospodarczej inicjatywie.

W polu emocjonalno-prywatnym kluczowy jest zabieg psychologizacji przedsiębiorcy. Wydaje się, że jako pierwszy sztuki tej dokonał J. Schumpeter, zanim rzecz jasna przystąpił do konstrukcji socjalistycznej utopii. Od przedsiębiorcy-kapitalisty wymagał on szczególnych predyspozycji osobowościowych: siły ducha i wielu, właściwych tylko nielicznym talentów (Schumpeter, 1960, s. 136-138). Jednocześnie osadza on przedsiębiorcę - istotę obrachunkową 
w świecie wartości uroczystych, stwierdzając, że gospodarcza inicjatywa kapitalisty ma charakter misyjny i niemal prometejski. To postać skomplikowana, wielowymiarowa, wychylająca się poza rachunek zysków i strat, poszukująca obszarów transgresji indywidualnej i realizująca swój cel istnienia. Dążenie do „przekraczania siebie” czyni zeń ostatecznie homo creator - marzyciela, który odnajduje satysfakcję w „zwyciężaniu nie dla owoców, lecz dla samego zwyciężania" (Mikosik, 1999, s. 149). Ostatecznie też daje się rozpoznać jako propagator bergsonowskiej „radości tworzenia” i urzeczywistnienie élan vital - pędu życia, który wyjawia się w kreowaniu nowatorskich form (Kołakowski, 2008, s. 73).

Kwintesencją pola trzeciego jest przeniesienie emocjonalności w obszar wartościowania. Implikuje to model przedsiębiorczości uwrażliwionej na naturę i piękno. To również przedsiębiorczość filantropijna - przejęta losem drugiego człowieka i gotowa zrezygnować z maksymalizacji zysku dla "transcendentaliów”. To także przedsiębiorczość stająca się "sensem życia”, szansą na autoafirmację i osobiste transgresje. Przez to też, ten typ przedsiębiorczości wypada określić mianem „romantycznej”. Jest on misją przekształcania świata, marzeniem o jego udoskonaleniu. I przez to skazany zostaje nierzadko na osamotnienie: funkcjonuje w okopach prywatności bez aspiracji do systemowego wsparcia. Jednocześnie szuka ideologicznej podbudowy, która nierzadko sprowadzona zostaje do poziomu indywidualnego systemu motywacji i coachingu.

Pole czwarte jest ostatnią częścią schematu. Jego kwintesencją jest połączenie emocjonalności z upublicznieniem, a wyróżnikiem intersubiektywność. Dochodzi w nim do przeniesienia afektu w obszar wartościowania. To z kolei oznacza, że przedsiębiorczość i model człowieka w gospodarce realizuje się w sposób międzypodmiotowy; ani na poziomie jednostkowych marzeń i ambicji, ani też poprzez systemową maszynerię. Nie jest indywidualnym planem, ani też „produktem systemu”. Wyłania się za to w procesie społecznego współtworzenia. Jej naturalnym matecznikiem jest przestrzeń międzyludzkich kontaktów. O takiej przedsiębiorczości przesądzają nabyte w drodze socjalizacji trwałe dyspozycje - habitusy. Transmitują one kulturę ekonomiczną danego regionu z pokolenia na pokolenie. Kulturę tę da się zidentyfikować na dwóch poziomach: socjalizacyjnym oraz ideowym (Kochanowicz, 2010, s. 18). „Służy [ona] - pisze J. Hryniewicz (2004, s. 190) - do wyjaśniania procesów upodobniania się zachowań indywidualnych i kształtowania się jednorodnych zachowań zbiorowych". To w niej zawiera się „ukryty wymiar, zespół przekonań, które (...) zostają zepchnięte za próg świadomości” (Hampden-Turner, Trompenaars, 2003, s. 11).

Ten właśnie ukryty wymiar ma moc formowania przedsiębiorczych osobowości. Dowodzą tego m.in. badania D. McClellanda (1961), który opisuje entrepreneurial spirit w kontekście typów motywacji, ukształtowanych w procesie wywoławczym, jak również analizy E. Hagen (1962), który zauważa związek pomiędzy typem osobowości przedsiębiorczej a lokalną kulturą. Nie można jednak stwierdzić, by w „polu czwartym” przedsiębiorczość stała się prostym produktem procesu socjalizacyjnego. Ćwiartka ta wszak ma charakter ontologicznie niedomknięty. Jej osie wyznaczają kierunek, ale nie koniec pola. Przedsiębiorczość formuje się tu w sposób relacyjny. Obszar ten zrywa zarówno z tradycją homo oecnomicus i homo sesitivo jak również homo sociologicus. Jednocześnie bazuje na tym co między-podmiotowe i podzielane. Dlatego też pasuje do niego model człowieczeństwa określony przez M. Archer mianem relacyjnego. Na tej też bazie konstruuje się kolejny typ przedsiębiorczości.

Człowieczeństwo relacyjne przeciwstawia się wszelkim uproszeniom. Funkcjonuje ono w trzech porządkach jednocześnie: naturalnym, pragmatycznym i społecznym. „Z tej perspektywy - przekonuje Archer (2013, s. 90) - jednostkowe własności i siły nie są nam uprzednio dane 
i nie nabywamy ich w ramach procesu socjalizacyjnego. Mają one pewien zakres autonomii zarówno wobec naszej biologicznej konstrukcji, jak i społeczeństwa, i są w stanie doprowadzać do ich zmiany". Jednostka nie tylko jest kształtowana przez porządek społeczny, ale również sama na niego oddziałuje i stwarza go. Cechuje ją przy tym refleksyjność. Kwintesencją modelu zaproponowanego przez Archer jest sprawstwo. Formuje się ono w oparciu o osobiste troski podmiotu i jednostką tożsamość, która jednak realizuje się w ramach systemu. W rezultacie model człowieczeństwa relacyjnego pozwala spojrzeć na przedsiębiorczość, tak jak życzyłby sobie tego M. Granovetter (1973) czy K. Polanyi (1957). Pierwszy ze wskazanych autorów przekonuje bowiem, że gospodarka jest zanurzona w relacjach społecznych (Grzesiuk, 2015, s. 90). Drugi pisze o instytucjonalnym jej zakorzenieniu. Zadaniem Polanyi'ego życie gospodarcze ma charter multirelacyjny. Gospodarka nie jest jakimś izolowanym światem, w którym człowiek może się zanurzyć, wykluczając inne porządki (Grzesiuk, 2015, s. 88). Ludzie w swych gospodarczych działaniach kierują się bowiem rozmaitymi pobudkami, a nie tylko maksymalizacją korzyści (Kassner, 2017, s. 49). I ten też fakt eksponuje ćwiartka czwarta, gdzie na plan pierwszy zostaje wysunięte znaczenie kapitału moralnego. To kategoria, która unaocznia wagę w cnót takich jak zaufanie, sprawiedliwość, lojalność i szacunek. Jednocześnie przeciwstawia się światom gospodarczym ufundowanym na wyzysku, obojętności, atrofii więzi, manipulacji i cynizmie (Sztompka, 2016, s. 154).

W polu czwartym przedsiębiorczość uwalnia się zarówno z ograniczeń modelu homo ocenonomicus, jak również nie daje zamknąć się w granicach systemu. W tym też kontekście szczególnej aktualności nabierają ustalenia A. Etzioniego, który przekonuje, że jednostka dysponuje dwoma źródłami wartościowania celów: przyjemnością i moralnością. Jednocześnie badacz ten zauważa, że są sytuacje, w których użyteczność moralna musi „zwiać górę”. Tylko ona bowiem kształtuje zachowanie jednostki w sposób imperatywny i unieważnia refleksyjność kalkulacyjną. Jest przede wszystkim aktem moralnym, który nie podlega obrachunkom (Musialik, 2016, s. 92).

\section{Typy przedsiębiorczości i czas pandemii SARS-CoV-2}

Schemat skonstruowany w oparciu o dwa podstawowe wymiary aktywności człowieka (obszar realizacji i podstawową ich przyczynę) pozwalają zidentyfikować cztery odmiany, czy inaczej: typy podstawowe przedsiębiorczości. Typologia ta, jak wszystkie inne, służy systematyzacji badanego zjawiska. Z jednej strony określa jego ramy pojęciowe; z drugiej - dostarcza porównawczego modelu. Uformowana w oparciu o schemat "dwóch osi” typologia pozwala wyróżnić przedsiębiorczość: zinstrumentalizowaną, zdepersonalizowaną, zindywidualizowaną i relacyjną.

Przedsiębiorczość zinstrumentalizowana jest przypisana do pola pierwszego i wykazuje powiązanie z modelem homo oecnonomicus. Właściwa jest jej aksjologia wsobność legitymizująca ochronę własnego interesu i lekceważenie dobra innych. Jej metodologicznym fundamentem jest atomizm. Pozwala on lekceważyć prawa wspólnoty i zwalnia jednostkę z zobowiązań wobec nich. W dobie pandemii SARS CoV-2 przedsiębiorczość zinstrumentalizowana realizuje się w dwojaki sposób: neutralny aksjologicznie lub patologiczny. W pierwszej formule eksponuje znaczenie racjonalności w gospodarczej inicjatywie i eliminuje emocje, które nierzadko blokują działanie. Centralną wartością tego typu przedsiębiorczości pozostaje zysk. Nadzieja na jego maksymalizację dopinguje do wytężenia aktywności i podejmowania się kolejnych inicjatyw, w tym nawet tych związanych z ryzykiem utraty zdrowia. Nastawienie takie skut- 
kuje nie tylko zawyżaniem cen oferowanych dóbr i usług, ale również przekłada się na szeroko rozumianą innowacyjność gospodarczą. Powołuje do istnienia m.in. firmy dostarczające pożywienie i codzienne zakupy w czasie ostrego lockdownu. Stwarza zakłady produkujące sprzęt ochronny (w tym materiałowe maseczki), czy też dopinguje do podjęcia się usług fryzjerskich w domu klienta. Te ostatnie z wymienionych określić należy mianem dewiacyjnych. Według R.K. Mertona (1982) tego typu innowacyjność jest naturalną odpowiedzią na stan anomii. Anomia bowiem „powołana zostaje do życia” poprzez dezintegrację kulturowo określonych celów i strukturalnie dostępnych środków do ich realizacji.

Z kolei wersja patologiczna przedsiębiorczości zinstrumentalizowanej nie tylko eksponuje znaczenie zysku i igra z zasadą odpowiedzialności, ale również ostentacyjnie lekceważy wszelkie inne reguły. Realizuje się pod hasłem maksymalizacji zysku i „zbijania kapitału” kosztem pogwałcenia aksjologicznego ładu epidemii. Model ten wzrasta na radykalnym odstępstwie od systemowej reguły. Jego istnienie legitymizuje stan atrofii i osłabienie emocjonalne, które pozwala bezpardonowo robić „interesy na panice”. Taka formuła w rezultacie nie gardzi możliwością dokonania oszustwa. Ostatecznie zapisuje się jako „przekręty” z czasów pandemii, polegający np. na dostarczeniu milionów bezwartościowych maseczek.

Przedsiębiorczość zdepersonalizowaną jest przypisana do pola drugiego i prowadzi do ograniczenia uczestnictwa jednostki w procesie gospodarczym. Na poziomie konceptualnym występuje w wersji umiarkowanej (gdy czyni z jednostki - przedsiębiorcy zakładnika systemu) lub rygorystycznej (gdy likwiduje przedsiębiorcę zastępując go aparatem bezimiennej administracji). Nadrzędną rolę ogrywa tutaj system, który przedsiębiorczość traktuje jako jedną z swoich funkcji. Działa on pod różnymi hasłami: bezpieczeństwa materialnego, dobrobytu, interwencjonizmu gospodarczego czy też zabezpieczenia socjalnego. Zadanie „zabezpieczenia socjalnego" wydaje się szczególnie istotne w dobie pandemii SARS CoV-2. Wymusza na systemach społecznych przebudowę ładu i określa nowe zasady funkcjonowania. Dotyczą one też przedsiębiorczości, która staje się jedną z funkcji systemu. Ma ona wykonywać zadania istotne z punktu widzenia logiki systemu i jego "struktury sensu”. Jej kwintesencją przez to też nie jest już indywidualny zysk, ale raczej racjonalność systemu. Realizuje się ona na poziomie zanonimizowanym, w wielkich firmach, których możliwości produkcyjne (np. Orlen produkujący płyn do dezynfekcji, General Motors w USA wytwarzający respiratory) zostają wykorzystane na rzecz walki z chorobą COVID-19. To również przedsiębiorczość, którą znamionuje deindywidualizacja. Jest ona skrajnie podporządkowana machinie systemowej (np. zarządzeniom o czasowym zawieszeniu działalności gospodarczej) i bezwzględnie poddaje się jej wyrokom, nawet wówczas gdy zagrażają one jej dalszemu funkcjonowaniu.

Przedsiębiorczość zindywidualizowana jest przyporządkowana do pola trzeciego i kształtuje się w oparciu o właściwą istocie ludzkiej emocjonalność. Z tej też przyczyny przedsiębiorczość zindywidualizowana daje rozpoznać się jako projekt o charakterze egzystencjalnym, ukierunkowany na poszukiwanie sensu i realizację osobistej misji. Nierzadko ten typ przedsiębiorczości dysponuje indywidualnym zapleczem ideologicznym, podtrzymującym zaangażowanie w gospodarczą inicjatywę. Wydaje się też wspierać na innym gatunku "egoizmu" aniżeli model homo oeconomicus. To egoizm ufundowany na afekcie. Znajduje on urzeczywistnienie w zrywnej filantropii, przedsiębiorczym marzycielstwie i sentymentalizmie. Sytuacje kryzysowe, w tym pandemia SARS-CoV-2, są naturalnym środowiskiem tego typu przedsiębiorczości. Pozwalają one realizować w pełni "charyzmat" przedsiębiorczości zindywidualizowanej. Eksponują też jej misyjny i idealistyczny charakter. W czasie pandemii SARS-CoV-2 przedsiębiorczość indywidualizowana urzeczywistnia się pod szyldem gospodarczej 
inicjatywy osobiście zaangażowanej w walkę z koronawirusem. Kategoria opłacalności nie jest jej kręgosłupem. Co więcej, wydaje się ustępować miejsca innym wartościom, w szczególności tym o charakterze egzystencjalnym. Jej przejawem jest dobroczynność finansowa i rzeczowa (np. nieodpłatne przekazywanie środków ochrony, czy obiadów dla służby zdrowia), jak również dobroduszność w relacjach kontrahenckich (np. utrzymanie zatrudnienia mimo braku przesłanek typu zyskownego). Przedsiębiorczość zindywidualizowana realizuje się także pod hasłem innowacyjności. Stymuluje ona przedsiębiorców-marzycieli do intensywnej wynalazczej pracy na rzecz „ratowania świata”. Wydaje się, że dobrym exemplum takiej działalności są inicjatywy milionera i filantropa B. Gatesa, który nierzadko jednak przez zwolenników teorii spiskowych jest oskarżany o "sterowanie światem".

Przedsiębiorczość relacyjna jest właściwa dla ostatniego w wymienionych obszarów. Opiera się na relacyjnym, międzypodmiotowym uczestnictwie w gospodarce. Ten typ przedsiębiorczości uobecnia się w świecie, w którym wartości funkcjonują w postaci kapitału moralnego. Przedsiębiorczość relacyjna przełamuje ograniczenia pozostałych wzorców, a jednoczesnej pozostaje konstrukcją „ontologicznie otwartą”. Jej kręgosłupem jest kategoria sprawczości. Uwzględnia ona zarówno troski i tożsamość jednostkową, jak również ograniczenia strukturalne systemu. Ostatecznie podmiotowi działania przypisuje też kluczową dla istnienia w gospodarce cechę. Jest nią refleksyjność. Wzorzec ten określić można również mianem przedsiębiorczości spersonalizowanej. W myśl założeń przyjętych przez personalistów człowiek bowiem powołany jest do autoafirmacji w czynie, jak również budowania wspólnoty. Działa w sposób wolny i świadomy (Kapias 2014, s. 153). Nie daje się zniewolić schematem, ale samoogranicza się wspólnotowymi wymogami. W rezultacie stwarza międzypodmiotową gospodarkę, która jest nadzieją współczesnego świata i odpowiedzią na wyzwania czasu kryzysu.

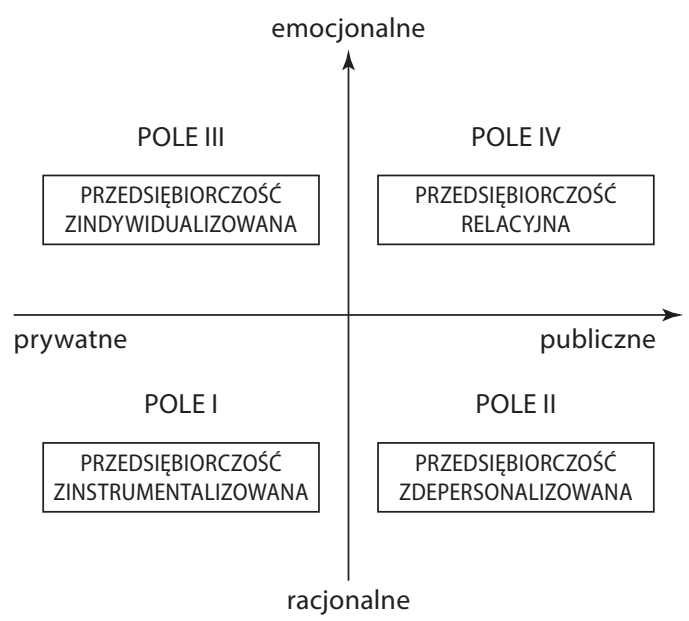

Rysunek 3. Modele podstawowe przedsiębiorczości

Źródło: opracowanie własne.

Typ ten pozostaje jednak w dużej mierze idealnym modelem, punktem odniesienia dla form, które się faktycznie urzeczywistniają. Dla tego typu przedsiębiorczości kluczowa wydaje się solidarność. To ona stanowi naturalny pomost pomiędzy dwoma innymi kluczowymi dla ładu systemowego wartościami: wolnością i sprawiedliwością społeczną. Solidarność godzi 
w sobie bowiem właściwą istocie ludzkiej potrzebę samorealizacji z moralnym przymusem podporzadkowania wspólnocie. Wyeksponowanie jej w modelu przedsiębiorczości jest szczególnie ważne w dobie pandemii SARS-CoV-2. Sytuacja ta zgłasza zapotrzebowanie na uformowanie nowego, aksjologicznie ukształtowanego modelu przedsiębiorczości. Tendencja pomnażania zysku winna zostać w nim poddana korekcie aksjologicznej. Model relacyjny jednocześnie harmonizuje właściwą istocie ludzkiej emocjonalność z racjonalnością systemu społecznego, w tym ze szczególną jej odmianą - racjonalnością materialną. Legitymizuje ona realizację projektów, których celem nie jest tylko i wyłącznie zysk. Racjonalność materialna wyraża "strukturę sensu" systemu społecznego i pozwala zaangażować przedsiębiorczość w ochronę wartości priorytetowych. Przedsiębiorczość w tej odmianie nie pozostaje jednak niewolnikiem systemu. Nie jest też indywidualnym projektem romantycznej filantropii ani elementem chciwej rynkowej gry. Realizuje się za to w sposób międzypodmiotowy. Funkcjonuje przy wsparciu systemu, z którym nieustannie negocjuje swoją ostateczną formułę. Z jednej strony umożliwia samorealizację i potrzebuje emocjonalnego zapału, z drugiej - korzysta z systemowej racjonalności i odwołuje się do "struktury sensu" całego systemu. Przez to też model ten wspiera się i korzysta z jednostkowego zapału i „marzeń", ale jednocześnie nie pozostawia ich samych. Wspiera je i formułuje wobec nich konkretne wymagania. W ten też sposób przedsiębiorczość relacyjna nie zostaje zakneblowana bezlitosnym prawem lockdownu. Nie dysponuje narzędziami do „oszukiwania systemu”. Jej spoiwem jest bowiem kapitał moralny, który zobowiązuje do przyzwoitości w gospodarce. Ta właśnie forma kapitału staje się sercem systemu, kwintesencją jego ładu, który wspierając gospodarczą inicjatywę, angażuje ją ostatecznie w walkę z pandemią SARS-CoV-2.

\section{Zakończenie}

Tak też okazuje się, że sytuacja, z którą świat zmaga się od początku 2020 roku, pozwala ostatecznie zdiagnozować cztery podstawowe typy przedsiębiorczości (rysunek 3). Nie przez przypadek łączą się one z określonymi modelami człowieczeństwa. Te zaś unaoczniają wyzwania dla współczesnych gospodarek i ukrytej w niej idei humitas, która niezmienne pozostaje zawieszona pomiędzy privatum i publicum; tym co emocjonalne i racjonalne.

Modele dające się wyprowadzić, z kluczowego dla niniejszej analizy schematu, służyć mają diagnozie stymulatorów i hamulców, szans i zagrożeń dla gospodarczej inicjatywy w dobie pandemii wirusa SARS-CoV-2.Nie ulega wątpliwości, że pełna analiza i ostateczne wnioski w tym zakresie możliwe będą do sformułowania dopiero w momencie wypracowania właściwego sprawie dystansu czasowego. Dziś podstawowym zadaniem staje się opracowanie właściwych konstrukcji pojęciowych i narzędzi analizy, umożliwiających opis zaistniałych fenomenów ex ante, jak również ex post. Konstrukcją tą jest zaprezentowana typologia. Jej poszczególne typy uprawdopodabniają opis, ocenę i interpretację możliwych już teraz do zaobserwowania społecznych fenomenów. Jednocześnie wydaje się, że zawierają w sobie pewną potencjalność, która ustrzeże je przed szybką dezaktualizacji.

Zaprezentowane typy, a w szczególności ostatni ze wskazanych, jest również postulatem zmiany i wypracowania nowej jakości „życia gospodarczego”. Jego kwintesencją jest przełamanie ograniczeń modeli człowieka ekonomicznego i uspołecznionego, które urzeczywistnia się we wpisaniu gospodarczej inicjatywy w przestrzeń „aksjologicznie wymagającą”. To ona właśnie czyni z przedsiębiorczości niełatwe zadanie. W myśl jej założeń przedsiębiorczość przestaje być czystym obrachunkiem, czy inną indywidualną ekspresją, a staje się w pewnym sen- 
sie „aktem moralnym”. Być może właśnie pandemiczna sceneria pozwoli kwestii tej wybrzmieć jeszcze głośniej. Wszak z pola napięć kategorii sobie przeciwstawnych wyłania się ostatecznie model przyszłości. To przedsiębiorczość relacyjna. Na mocy „intersubiektywności” pozwala ona pokonać emocjonalną barierę wsobności. Jednocześnie ufundowany na „upublicznieniu emocjonalności" model zobowiązuje przedsiębiorczość do solidaryzmu i orientuje ją na wspólnotę. Nie czyni jednak zakładnikiem logiki systemowej. I na tym polega jej fenomen.

\section{Literatura}

Archer, M. (2013). Człowieczeństwo. Problem sprawstwa. Kraków: Nomos.

Bauman, Z. (1959). Socjologia Vilfreda Pareta. Archiwum Historii Filozofii i Myśli Społecznej, V, 5-38.

Coleman, J. (2008). Perspektywa racjonalnego wyboru w socjologii ekonomicznej. W: A. Jasińska-Kania i in. (red.). Współczesne teorie socjologiczne. Warszawa: Wydawnictwo Naukowe Scholar.

Dzionek-Kozłowska, J. (2018). Homo oeconomicus. Geneza, ewolucja, wpływ na rzeczywistość gospodarcza. Łódź: Wydawnictwo Uniwersytetu Łódzkiego.

Etzioni, A .(1988). The Moral Dimension: Toward a New Economics. New York, London, Toronto, Sydney, Singapore: The Free Press.

Giza-Poleszczuk, A. (2010). Gospodarka i uczucia moralne. W: J. Kochanowicz, M. Marody (red.). Kultura i gospodarka (s. 247-274). Warszawa: Wydawnictwo Naukowe Scholar,.

Granovetter, M. (1973). The Strength of Weak Ties. American Journal of Sociology, 78(6), 1360-1380.

Grzesiuk, K. (2015). Zakorzenienie społeczne gospodarki. Koncepcja Marka Granovettera. Lublin: Katolicki Uniwersytet Lubelski.

Hagen, E. (1962). On the Theory of Social Change. How Economic Growth Begins. Homewood: The Dorsey Press Inc.

Hampden-Turner, Ch., Trompenaars, A. (2003). Siedem kultur kapitalizmu. USA, Japonia, Niemcy, Francja, Wielka Brytania, Szwecja, Holandia. Kraków: Oficyna Ekonomiczna.

Hryniewicz, J. (2004). Polityczny i kulturowy kontekst rozwoju gospodarczego. Warszawa: Wydawnictwo Naukowe Scholar.

Kapias, M. (2104). Homo oeconomicus versus homo personalis. Człowiek pomiędzy ekonomią a etyką. Ruch filozoficzny, LXXI (2), 143-159.

Kassner, M. (2017). Gospodarka jako zinstytucjonalizowany proces. Instytucjonalizm Karla Polanyiego i jego etyczne konsekwencje. Annales. Etyka w Życiu Gospodarczym, 20(2), 45-61.

Kłoskowska, A. (2007). Socjologia kultury. Warszawa: Wydawnictwo Naukowe PWN.

Kochanowicz, J. (2010). Duch kapitalizmu na polskiej peryferii. Perspektywa historyczna. W: J. Kochanowicz, M. Marody (red.), Kultura i gospodarka (s. 21-51). Warszawa: Wydawnictwo Naukowe Scholar.

Kołakowski, L. (2008). Bergson. Kraków: Znak.

Luhmann, N. (2007). Systemy społeczne. Kraków: Nomos.

Marody, M. (2015). Jednostka po nowoczesności. Perspektywa socjologiczna. Warszawa: Wydawnictwo Naukowe Scholar.

Marody, M., Giza-Poleszczuk, A. (2004). Przemiany więzi społecznych. Zarys teorii zmiany społecznej. Warszawa: Wydawnictwo Naukowe Scholar.

McClelland, D. (1961). The Achieving Society. Princeton: Van Nostrand.

Merton, R., K. (1982). Teoria socjologiczna i struktura społeczna. Warszawa: Państwowe Wydawnictwo Naukowe.

Mikosik, S. (1999). Teoria rozwoju gospodarczego Josepha A. Schumpetera. Warszawa: Wydawnictwo Naukowe PWN.

Mill, J., S. (1962). System logiki dedukcyjnej i indukcyjnej. T.2. Warszawa: PWN.

Mill, J., S. (1836/1967). On the Definition of Political Economy; and on the Method of Investigation Proper to It. W: J. M. Robson (red.). Collected Works of John Stuart Mill, vol. IV (Essays on Economics and Society) (s. 309-339). London: University of Toronto Press, Routledge \& Kegan Paul.

Musialik, R. (2016). Koncepcja wartości Amitaia Etzioniego. Studia Ekonomiczne. Zeszyty Naukowe Uniwersytetu Ekonomicznego w Katowicach, 259, 89-97.

Oleś, P. (2005). Wprowadzenie do psychologii osobowości. Warszawa: Wydawnictwo Naukowe Scholar.

Pareto, V. (1964). Trattato di sociologia generale. Mediolan: Edizioni di Comunità. 
Pareto, V. (1975). Umysł a społeczeństwo. W: W. Dereszyński, A. Jasińska-Kania, J. Szacki (red.) Elementy teorii socjologicznych. Materiały do dziejów współczesnej socjologii. Warszawa: PWN.

Parsons, T., Shils E., Olds J. (2006). Kategorie orientacji i organizacji działania. W: A. Jasińska-Kania, L. M. Nijakowski, J. Szacki, M. Ziółkowski, Współczesne teorie socjologiczne (s. 376-389). Warszawa: Wydawnictwo Naukowe Scholar.

Parsons, T. (2009). System społeczny. Kraków: Nomos.

Polanyi, K. (1957). The Great Transformation. The Political and Economic Origins of Our Time. Boston: Beacon Press. Schumpeter, J. (1960). Teoria rozwoju gospodarczego. Warszawa: Państwowe Wydawnictwo Naukowe.

Schumpeter, J. (1995). Kapitalizm, socjalizm, demokracja. Warszawa: Państwowe Wydawnictwo Naukowe.

Smith, A. (1989). Teoria uczuć moralnych. Warszawa: Państwowe Wydawnictwo Naukowe.

Smith, A. (2007). Badania nad natura i przyczynami bogactwa narodów. Warszawa: Wydawnictwo Naukowe PWN.

Sombart, W. (2010). Żydzi i życie gospodarcze. Warszawa: IFiS PAN.

Sztompka, P. (2016). Kapitał społeczny. Teoria przestrzeni międzyludzkiej. Kraków: Znak.

Sztompka, P. (2020). Słownik socjologiczny 1000 pojęć. Kraków: Znak.

Weber, M. (2005). Pojęcie działania społecznego, W: P. Sztompka, M. Kucia (red.). Socjologia. Lektury (s. 46-59). Kraków: Znak.

Weber, M. (1994). Etyka protestancka a duch kapitalizmu, Lublin: Wydawnictwo Test.

\section{Entrepreneurship in the era of SARS-CoV-2 pandemic. An attempt to identify areas for conceptual analysis and models of economic initiative actualisation}

Summary: The main goal behind this article is to develop tools for entrepreneurship analysis and typology. The individual types of entrepreneurship will serve as viable models of economic initiative in the era of SARSCoV-2 pandemic. Therefore, our ambition is to present ideal-type models for ex ante and ex post evaluation of pandemic events. The article is theoretical in nature, and relies on a discussion of specific views, terms and concepts. Through our analysis, we identified four primary models of entrepreneurship with their associated opportunities and risks brought to light by the epidemic developments.Our conceptual evaluation of ideal types of entrepreneurship ultimately leads to the development of a future model. This model is "relational entrepreneurship" which marries social and individual aspirations. In addition, it reconciles two basic forms of utility, economic and moral.

Keywords: entrepreneurship; pandemic; axiology, models of economic man; homo economicus

JEL codes: A14, Z13

\section{Informacje o autorce}

\section{Magdalena Zdun, dr hab., prof. UEK}

ORCID: 0000-0002-3784-2098

Katedra Geografii Społeczno-Ekonomicznej

Wydział Kolegium Gospodarki i Administracji Publicznej

Uniwersytet Ekonomiczny w Krakowie

ul. Rakowicka 27, 31-510 Kraków

e-mail:zdunm@uek.krakow.pl

Źródło finansowania badań: Publikacja została sfinansowana ze środków subwencji przyznanej Uniwersytetowi Ekonomicznego w Krakowie: Program Potencjał „Rozwój społeczno-gospodarczy w analizach teoretycznych i diagnostyce empirycznej" nr 51/GGG/2020/POT. 


\section{Prawa autorskie i licencja / Copyright and License}

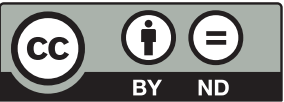

Publikacja na licencji Creative Commons Uznanie autorstwa Użycie niekomercyjne - Bez utworów zależnych 4.0 Międzynarodowe (CC BY-ND 4.0) http://creativecommons.org/licenses/by-nc-nd/4.0/deed/pl

This work is published under the terms of the Creative Commons

Attribution - NoDerivetives International (CC BY-ND 4.0) License http://creativecommons.org/licenses/by-nc-nd/4.0

Wydane przez Uniwersytet Ekonomiczny w Krakowie. Małopolska Szkoła Administracji Publicznej

Published by Cracow University of Economics - Krakow, Poland. Małopolska School of Public Administration of the Cracow University of Economics 